\title{
Environmental influences on patterns of larval replenishment in coral reef fishes
}

\author{
David T. Wilson ${ }^{1,2, *}$, Mark G. Meekan ${ }^{2}$ \\ ${ }^{1}$ Department of Marine Biology, James Cook University, Townsville, Queensland 4811, Australia \\ ${ }^{2}$ Tropical Fisheries, Australian Institute of Marine Science, PMB 3, Townsville, Queensland 4810, Australia
}

\begin{abstract}
Spatial and temporal patterns of larval replenishment to the San Blas Archipelago were measured using 3 light traps in each of 3 habitats (exposed, lagoon and back-reef) over 18 lunar months from December 1996 to June 1998. Traps were sampled for 19 consecutive nights centred on the new moon in each month. The effects of environmental variables (wind speed and wind direction, tidal range, rainfall, solar radiation and water temperature) on catches were examined both in the days immediately prior to settlement and during the entire larval phase using 2 approaches. Firstly, time-series analyses were used to compare night-to-night patterns in light trap catches of 11 species (Astrapogon puncticulatus, Eucinostomus melanopterus, Lutjanus apodus, L. mahogani, Ophioblennius atlanticus, Stegastes dorsopunicans, S. partitus, S. planifrons Synodontidae spp., Thalassoma bifasciatum and an unidentified blenny) with environmental variables. Secondly, modified correlation analysis was used to examine the relationships between environmental variables, averaged over larval durations, and light trap catches of 6 of these species. Time-series analysis detected significant correlations between catches of 8 species and wind direction; however, correlations were often weak and variable in direction. Similarly, there were weak correlations between day-to-day catches of all but 3 species and water temperature. Modified correlation analysis also found that water temperature was correlated with catches of 4 species (Lutjanus mahogani, Stegastes dorsopunicans, S. partitus and S. planifrons). Catches of the remaining species, Ophioblennius atlanticus and Thalassoma bifasciatum, were not correlated with environmental variables in these analyses. Multiple-regression analysis could not detect any combined effects of environmental variables on patterns of light trap catches, although this analysis also identified weak correlations $\left(\mathrm{R}^{2}=0.08\right.$ to 0.29$)$ between catches of Lutjanus mahogani, Ophioblennius atlanticus, Stegastes dorsopunicans, S. partitus, S. planifrons and Thalassoma bifasciatum and water temperature.
\end{abstract}

KEY WORDS: Larval replenishment $\cdot$ Light traps $\cdot$ Larval fish $\cdot$ Environment $\cdot$ Water temperature · Wind component · Time-series

Resale or republication not permitted without written consent of the publisher

\section{INTRODUCTION}

Studies examining the influence of environmental variables on the delivery of tropical reef fish larvae from the plankton to juvenile and adult populations have generally examined the processes occurring

\footnotetext{
*Present address: Department of Marine and Wildlife Resources, PO Box 3730, Pago Pago, AS 96799, USA.

E-mail: dave_t_wilson@hotmail.com
}

immediately prior to, or at the time of settlement into benthic habitats (Milicich 1994, Thorrold et al. $1994 a, b, c)$. The focus on this time in the life history reflects the perceived importance of factors that influence the dispersal of larvae at the end of their larval lives as determinants of replenishment patterns (Cowen \& Sponaugle 1997, Kingsford \& Finn 1997, Sponaugle \& Cowen 1997). However, such studies have varied in their ability to correlate the intensity of replenishment with potential transport mechanisms 
such as current flow or wind speed and direction. For example, Shenker et al. (1993) and Thorrold et al. $(1994 \mathrm{c})$ found that in the Bahamas the replenishment of several taxa of shore-fishes was influenced by longshore or cross-shelf currents and winds that generated peaks in settlement lasting several days. In contrast, an 11 yr study by Robertson et al. (1999) in Caribbean Panamá found little relationship between wind patterns and monthly recruitment of a common wrasse, Thalassoma bifasciatum. Similarly, Kingsford \& Finn (1997) found only weak correlations between the numbers of reef fishes arriving each night on a reef on the southern Great Barrier Reef (GBR) and wind speed or direction.

Recent studies that have examined the swimming and sensory abilities of reef fishes at the end of the pelagic stage may explain these results, as they suggest that older larval stages of some species are unlikely to be passively distributed by currents. Instead, such larvae appear to be accomplished swimmers capable of detecting reefs and controlling their distribution in the plankton (Leis et al. 1996, Leis \& Carson-Ewart 1997, 1999, Stobutzki \& Bellwood 1998). For many species, this behaviour may act to effectively decouple any link between transport processes and variation in replenishment at the end of the planktonic stage (Kingsford \& Finn 1997).

The emphasis on transport and dispersal in tropical studies contrasts with the approach in temperate systems where for nearly a century, fisheries ecologists have focused on the role of environmental processes occurring throughout the planktonic larval lives of marine fishes as determinants of survivorship and, ultimately, variability in replenishment (Cowen \& Sponagule 1997). Such studies implicate a range of environmental variables that may act independently or in unison to influence the survivorship of larvae within the plankton. For example, optimum light levels may enhance productivity and the availability of food resources for larvae, thus increasing survivorship (Heath 1992, Cushing 1995, Gallego et al. 1996). Such effects may be most critical during the first weeks of larval life, rather than when larvae are nearing the time of settlement (Theilacker et al. 1996). This suggests that any investigation of the influence of environmental processes on patterns of replenishment of reef fishes should not only focus on events occurring in the days near settlement, but should also examine their importance over the entire larval duration of study species.

Here we examine the influence of environmental variables on the replenishment of reef fishes in the San Blas Archipelago, Caribbean Panama. Measures of replenishment were derived from an 18 mo study that used light traps to sample reef fishes on their arrival in 3 nearshore habitats in the Archipelago (Wilson 2001).
We investigated the relative importance of processes acting both throughout larval life and just prior to settlement of young fish into the benthic habitats of adults, as determinants of the magnitude of replenishment to this locality. Two approaches were used to achieve this goal. Firstly, time-series analysis was used to compare day-to-day patterns in light trap catches with those of environmental variables such as wind strength and direction. Secondly, modified correlation analysis (Pyper \& Peterman 1998) was used to examine relationships between environmental variables throughout the entire larval stage and the magnitude of light trap catches. The 11 most abundant species collected in the traps during the 18 mo of the study were the subjects of these analyses.

\section{MATERIALS AND METHODS}

Biological sampling. Replenishment was monitored for 342 nights over 18 consecutive lunar cycles, using light traps, from December 1996 to June 1998 in the San Blas Archipelago $\left(9^{\circ} 34^{\prime} \mathrm{N}, 78^{\circ} 58^{\prime} \mathrm{W}\right)$. A detailed description of the study site and sampling program is given in Wilson (2001). Briefly, 3 traps were deployed on fixed moorings just below the surface in each of the exposed, lagoon and back-reef habitats (see Fig. 1b of Wilson 2001). Traps within a habitat were separated by ca $100 \mathrm{~m}$ and at a distance of 50 to $100 \mathrm{~m}$ from the reef margin. During each lunar month, traps were sampled for 19 consecutive nights centred on the new moon. Sampling during this period encompassed the time when the majority of larvae (90\%) arrived in benthic habitats (Robertson 1992, Wilson 2001).

Environmental variables. Environmental data were measured at and around the Smithsonian Research Station in San Blas. Wind speed and direction were monitored hourly using an R. M. Young anemometer (R. M. Young Co., Traverse City, Michigan) mounted on a tower $10 \mathrm{~m}$ above the water. Prior to these data being compared to nightly catches in traps, daily averages were calculated and wind speed and direction were combined into a single coarse wind component. Winds originating from the NW to E (315.1 to $\left.90^{\circ}\right)$ were categorised as positive (onshore) and winds from 90.1 to $315^{\circ}$ as negative (offshore) components (Milicich 1994).

Mean daily water temperatures were measured with a Hobo and Ryan temperature sensor (Onset Instruments, Pocasset, MA) at a depth of $6 \mathrm{~m}$. The sensors recorded temperature every $106 \mathrm{~min}$ and measurements were then interpolated to the nearest hour and a daily average calculated. The resolution of temperature readings was $0.25^{\circ} \mathrm{C}$. Daily totals of rainfall were monitored using a Stevens logger and encoder 
(Stevens Water Monitoring Systems, Leupold and Stevens, Inc., Beaverton, OR) while solar radiation was recorded as total $\mathrm{Wm}^{-2} \mathrm{~h}^{-1}$ using an Li-Cor sensor and logger (Li-Cor, Inc., Lincoln, NE). Local tidal variations were monitored using an automatic logger that calculated water levels every 6 s. Tidal range was calculated as the maximum minus the minimum tidal height each night.

Data analysis. Prior to analysis, catches from each 19 consecutive night period and environmental variables on the corresponding days were concatenated into a single, nightly time series of 342 nights. Each data point (night) was the mean catch of all light traps operating on that night. Data sets were transformed to $\ln (x+1)$ values in order to stabilise the variance. As the autocorrelation coefficients of most time series decayed exponentially, the data was also transformed using first-order differencing prior to analysis (Chatfield 1997). Auto regressive integrated moving average (ARIMA) models were then fitted to the data and the number of autoregressive (AR) and moving average (MA) parameters was determined by inspecting the autocorrelogram. The reliability of the model fit was confirmed by examining the autocorrelogram to ensure that autocorrelation had been removed. In addition, the residuals from the model were plotted to examine normality.

Cross-correlation techniques were then used to examine relationships between light trap catches and environmental variables using residuals from the ARIMA models. Only significant correlations between time series where environmental events preceded catches at lags $\leq 6 \mathrm{~d}$ are presented, as correlations at longer lags were considered unreliable (Kingsford \& Finn 1997). These analyses were run firstly on the entire data set and then separately on the data from wet and dry seasons.

Generally, time-series analysis has been used to examine relationships between autocorrelated data sets such as nightly catches in light traps and wind speed, water temperature and other environmental variables (Milicich 1994, Kingsford \& Finn 1997, Robertson et al. 1999). However, a recent study has shown that this type of analysis reduces statistical power by failing to include low-frequency signals in the data sets that may be important for correlation between variables (Pyper \& Peterman 1998). This was not considered to be a problem in the previous analysis, which focused on day to day patterns in light trap catches and day to day patterns in the environmental variables likely to affect the transport of larvae to reef habitats such as wind strength and direction. In contrast, the environmental variables likely to affect biological processes such as planktonic productivity will act over time scales of weeks to months, rather than days. For this reason, this analysis used a modified correlation analysis (described by Pyper \& Peterman 1998) in order to include both low- and high-frequency variation in the comparison of variables.

We firstly obtained estimates of the Planktonic Larval Durations (PLD) of the study species. This information was available for only 6 of the 11 species (Lutjanus mahogani $=27 \pm 3 \mathrm{~d}, \mathrm{n}=30$, Wilson unpubl. data; Ophioblennius atlanticus $=37 \pm 3 \mathrm{~d}, \mathrm{n}=40$ : Wilson unpubl. data; Thalassoma bifasciatum $=49.3 \pm$ 5.5 d, n = 1172: Victor 1986a, b; Stegastes dorsopunicans $=21.2 \pm 1.3 \mathrm{~d}, \mathrm{n}=10$ : Wellington \& Victor 1989; $S$. partitus $=33.9 \mathrm{~d} \pm 3 \mathrm{~d}, \mathrm{n}=281$ : Wilson \& Meekan in press; $S$. planifrons $=21.4 \pm 1.9 \mathrm{~d}, \mathrm{n}=12$ : Wellington $\&$ Victor 1989). The remaining species were not included in this analysis. These larval durations identified the period over which environmental variables were to be averaged. For example, in order to compare light-trap catches of $S$. dorsopunicans with wind speed, measurements from $21 \mathrm{~d}$ prior to each date of light-trap sampling were averaged (i.e. the mean PLD for this species). These time series of environmental variables and light-trap samples were then pooled into 3 intervals of equal duration in each month (6 nights) in order to account for the likely variation in larval duration among the individuals collected in a trap on any night of sampling and to reduce the influence of day-to-day variability in the magnitude of catches. This provided a series of $54 x-y$ data points. These were compared using correlation analysis with a test statistic modified using the procedure outlined by Pyper \& Peterman (1998). Briefly, this modification adjusts the test statistic to account for the amount of auto-correlation inherent in the data sets, thus reducing the chances of Type I error. In order to compare the importance of environmental variables during different phases of the larval duration, this analysis was repeated where only environmental variables measured during the first or second halves of the larval duration were included in the data sets. Thus, for the species in the above example, only wind speeds measured from 1 to 11 , or from 12 to $21 \mathrm{~d}$ prior to the date of capture were included in the data sets.

The data sets for these species were also correlated with environmental variables using multiple regression analyses. All variables were $\log _{10}$-transformed to improve linearity. Correlation matrices were calculated and, where a model selected 2 highly correlated variables, the variable that contributed most to the model was retained and the other discarded. This procedure ensured that the final estimate of correlation was not inflated due to non-independence of some variables. These analyses were run using STATISTICA (StatSoft, Tulsa, OK). 


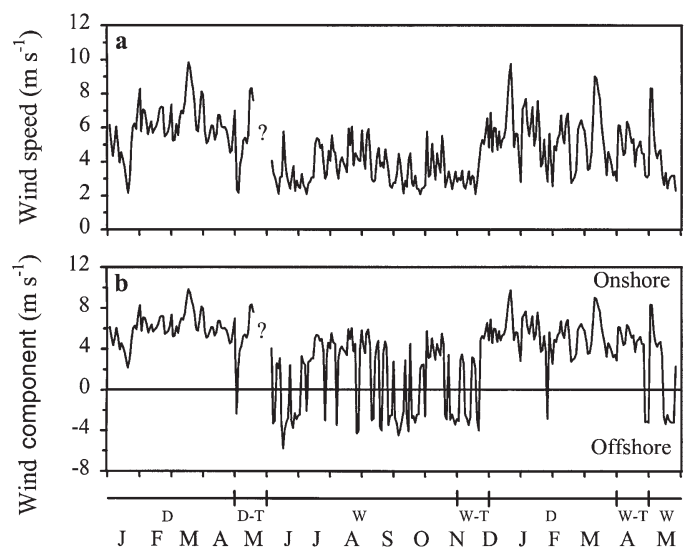

Fig. 1. (a) Wind speed, and (b) component during $19 \mathrm{~d}$ centred on the new moon in each of 18 consecutive lunar cycles from 31 December 1996 to 3 June 1998. Data sets have been concatenated into a single time series and ticks on $x$-axis mark start and end points of each lunar cycle. ? = missing data. Seasons are shown: dry (D), wet (W) and transitional month (T). Timing of calender months is also shown

\section{RESULTS}

\section{Environmental variables}

During the wet season, winds were weak (range = 2.1 to $6.5 \mathrm{~m} \mathrm{~s}^{-1}$, Fig. 1a) and variable in direction (Fig. 1b). During the dry season, winds were stronger and consistently onshore from the NNE, with only 2 episodes of offshore winds (range $=2.2$ to $9.8 \mathrm{~m} \mathrm{~s}^{-1}$ : Fig. 1). As expected, wind speed and wind component were strongly correlated (Table 1).

Rainfall peaked between May and November (Fig. 2a) and was negatively correlated with solar radiation (Fig. 2b, Table 1). Average water temperature during the study displayed a positive long-term trend, increasing between the first and second dry seasons (Fig. 2c). Tidal ranges were lower and had a stronger semi-diurnal pattern during the dry season than the wet

Table 1. Cross-correlation matrix (r) of environmental variables. $\mathrm{n}=342 \mathrm{~d}$, ns: not significant at $2 \times$ SE. Lag of correlation in (d) in parentheses

\begin{tabular}{|lccccc|}
\hline & $\begin{array}{c}\text { Wind } \\
\text { component }\end{array}$ & $\begin{array}{c}\text { Wind } \\
\text { speed }\end{array}$ & $\begin{array}{c}\text { Water } \\
\text { temperature }\end{array}$ & Rainfall & $\begin{array}{c}\text { Tidal } \\
\text { range }\end{array}$ \\
\hline Wind component & - & - & - & - & - \\
Wind speed & $0.58(0)$ & - & - & - & - \\
Water temperature & $-0.13(-6)$ & $0.14(2)$ & - & - & - \\
Rainfall & $0.13(-1)$ & $\mathrm{ns}$ & $0.16(-6)$ & - & - \\
Tidal range & $-0.13(0)$ & $\mathrm{ns}$ & $\mathrm{ns}$ & $\mathrm{ns}$ & - \\
Solar radiation & $0.12(4)$ & $\mathrm{ns}$ & $0.16(0)$ & $-0.44(0)$ & $-0.15(0)$ \\
& $0.19(0)$ & $0.20(4)$ & $0.28(1)$ & & \\
\hline
\end{tabular}
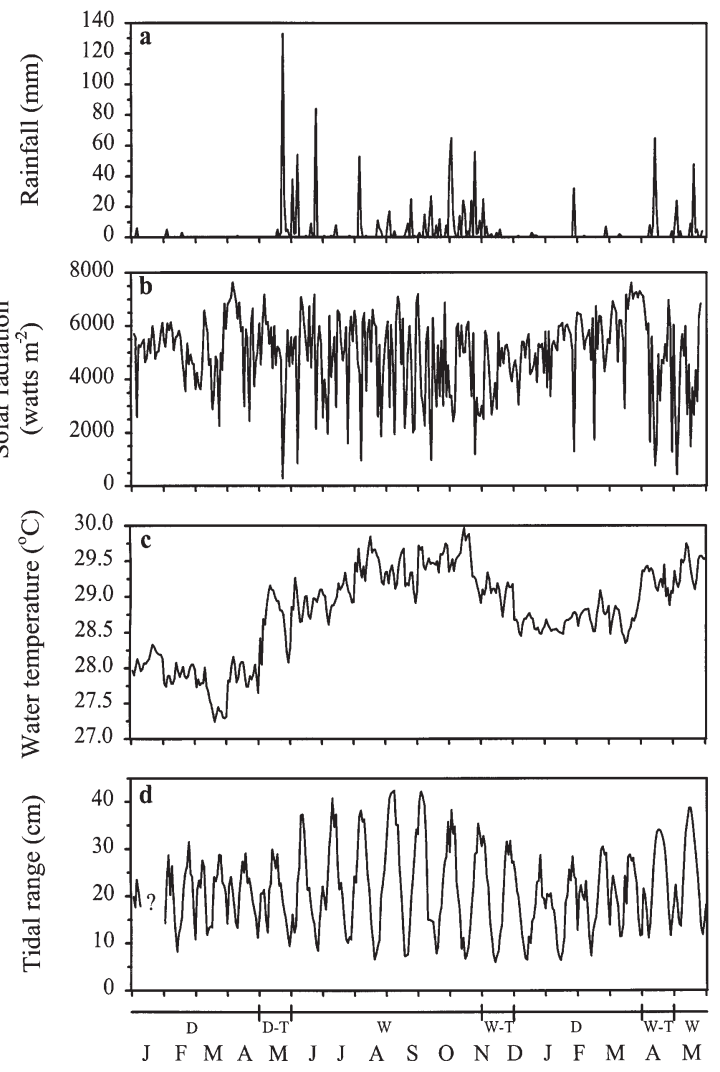

Fig. 2. (a) Daily rainfall, (b) solar radiation, (c) water temperature and (d) tidal range during $19 \mathrm{~d}$ centred on the new moon in each of 18 consecutive lunar cycles from 31 December 1996 to 3 June 1998. Data sets have been concatenated into a single time series and ticks on $x$-axis mark start and end points of each lunar cycle. Timing of calender months is shown. Other symbols as for Fig. 1

season (Fig. 2d). There were significant positive correlations between wind speed and water temperature, and water temperature and solar radiation (Table 1).

\section{Abundance of pre-settlement fishes in light traps}

Astrapogon puncticulatus, Eucinostomus melanopterus, Lutjanus apodus, L. mahogani, Ophioblennius atlanticus, Stegastes dorsopunicans, S. partitus, S. planiforns, Synodontidae spp., Thalassoma bifasciatum and an unidentified blenny (Blenniid Type 2) were the most abundant species collected by the light traps during the study. Figs 3, 4 \& 5 show the nightly pattern of catches for each of these 11 species and also the pattern pooled among all taxa collected 
Table 2. Cross-correlation coefficients (r) from comparisons of wind speed and component with catches of the 11 most abundant taxa collected by light traps during 19 nights of sampling centred on the new moon in each of 18 consecutive lunar cycles from 31 December 1996 to June 1998. Data sets of catches and wind were concatenated into single time series prior to analysis. ns: not significant at $2 \times \mathrm{SE}$. Lag in nights for correlation shown in parentheses. All: analysis using the entire time series $(\mathrm{n}=342$ nights); Wet: wet season time series $(\mathrm{n}=171$ nights); Dry: dry season time series $(\mathrm{n}=171$ nights $)$

\begin{tabular}{|c|c|c|c|c|c|c|}
\hline \multirow{2}{*}{ Taxa } & & \multirow{2}{*}{$\begin{array}{l}\text { Wind speed } \\
\text { Wet }\end{array}$} & \multirow[b]{2}{*}{ Dry } & \multirow[b]{2}{*}{ All } & \multirow{2}{*}{$\begin{array}{l}\text { Wind component } \\
\text { Wet }\end{array}$} & \multirow[b]{2}{*}{ Dry } \\
\hline & All & & & & & \\
\hline Astrapogon puncticulatus & ns & ns & ns & ns & ns & $\mathrm{ns}$ \\
\hline Blenniid Type 2 & $0.15(0)$ & ns & $0.18(0)$ & $\mathrm{ns}$ & ns & $\mathrm{ns}$ \\
\hline Eucinostomos melanopterus & $-0.11(1)$ & ns & ns & ns & ns & $\mathrm{ns}$ \\
\hline Lutjanus apodus & ns & ns & $-0.19(0)$ & $-0.13(0)$ & $-0.18(0)$ & $-0.19(0)$ \\
\hline Lutjanus mahogani & ns & ns & $-0.20(0)$ & ns & ns & $\begin{array}{r}0.18(2) \\
-0.22(5)\end{array}$ \\
\hline Ophioblennius atlanticus & $\mathrm{ns}$ & $\mathrm{ns}$ & $0.20(4)$ & $-0.12(0)$ & ns & ns \\
\hline Stegastes dorsopunicans & $\mathrm{ns}$ & $0.22(2)$ & $-0.17(0)$ & ns & ns & $\mathrm{ns}$ \\
\hline Stegastes partitus & ns & ns & ns & $\mathrm{ns}$ & ns & ns \\
\hline Stegastes planifrons & ns & ns & ns & ns & $-0.18(1)$ & ns \\
\hline Synodontidae spp. & $0.12(3)$ & $0.24(6)$ & $0.18(4)$ & $\mathrm{ns}$ & $-0.18(1)$ & $\mathrm{ns}$ \\
\hline Thalassoma bifasciatum & ns & $-0.18(0)$ & $-0.19(2)$ & ns & ns & $0.22(6)$ \\
\hline All taxa & ns & ns & ns & $-0.13(1)$ & ns & $0.23(6)$ \\
\hline
\end{tabular}

over the 18 lunar months of the study. Replenishment of each species was often sporadic, however most displayed an increase in abundance between the first and second dry seasons. This was reflected in patterns of total catches ('All taxa': Fig. 5). Most species had peaks in catches associated with the wet season months, although abundances of the unidentified blenny (Blenniid Type 2) peaked during the dry season. E. melanopterus and Synodontidae spp. did not display any strong seasonal variation in abundance, and were collected in similar numbers throughout both wet and dry seasons.

\section{Correlations between day-to-day patterns in light trap catches and environmental variables}

Correlations between wind speed, component and abundance patterns of each species were generally weak and variable (Table 2). While large catches of 2 damselfishes, Stegastes partitus and S. planifrons occured during periods of offshore winds between 2 and $4 \mathrm{~m} \mathrm{~s}^{-1}$ (Fig. 6), this pattern was sporadic, and with a single exception, correlations between catches of these species and wind speed and component were non-significant (Table 2). Lutjanus apodus was collected almost exclusively during offshore winds, as shown by the negative correlations with the wind vector over the entire sampling period (Table 2, Fig. 6). The remaining species displayed little correlation between the wind component and catches (Table 2, Fig. 6). Wind speeds during the wet season were positively correlated with nightly catches of $S$. dorsopuni-
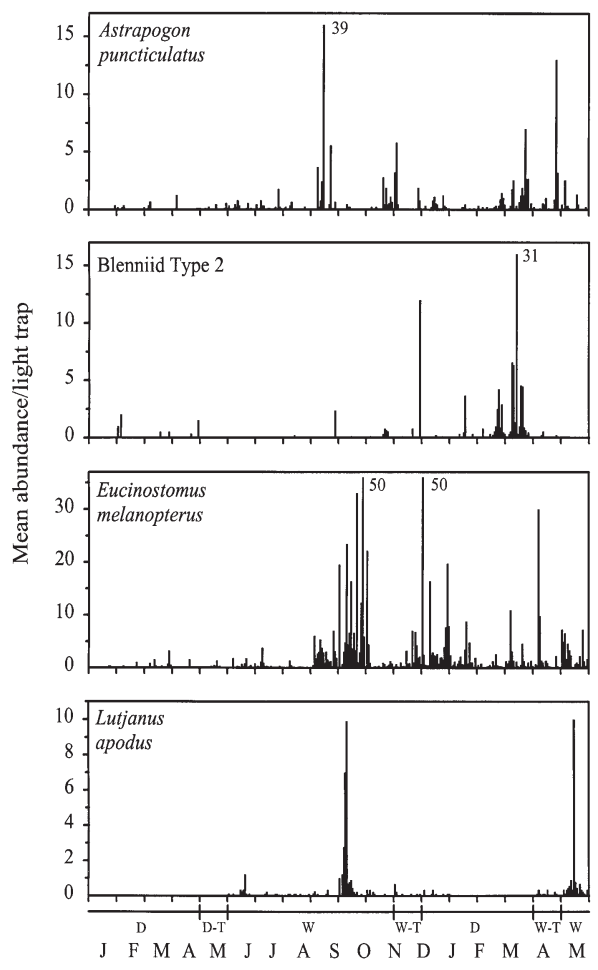

Fig. 3. Nightly catches of pre-settlement Astrapogon puncticulatus, Blenniid Type 2, Eucinostomus melanopterus and Lutjanus apodus by light traps, in the nearshore waters of San Blas Archipelago, during 19 nights centred on the new moon in each of 18 consecutive lunar cycles from December 1996 to 3 June 1998. Data sets have been concatenated into single time series and ticks on $x$-axis mark start and end points of each lunar cycle. Timing of calender months is shown. Large peaks in catches are truncated and mean abundance given on plot. Other symbols as for Fig. 1 


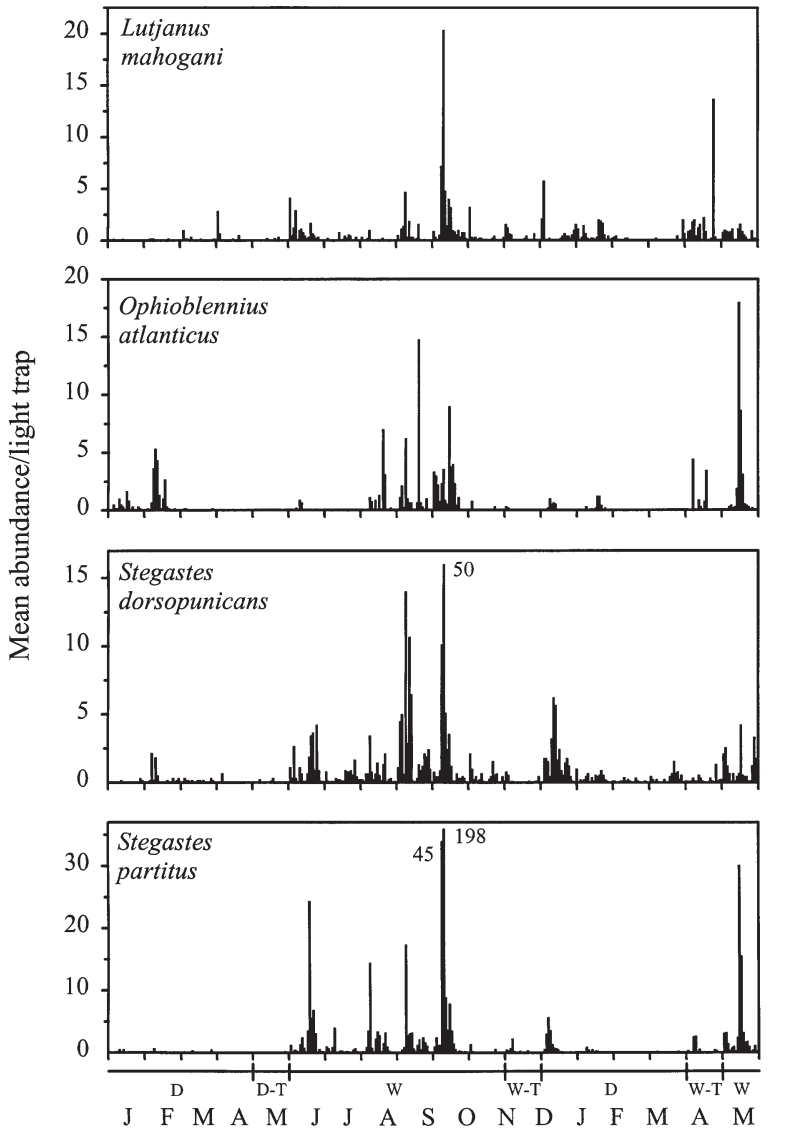

Fig. 4. Nightly catches of pre-settlement Lutjanus mahogani, Ophioblennius atlanticus, Stegastes dorsopunicans and $S$. partitus. Time series and symbols as for Fig. 3

cans and Synodontidae spp. at lags of $2(\mathrm{r}=0.22)$ and 6 $(\mathrm{r}=0.24)$ nights respectively, and negatively correlated with Thalassoma bifasciatum at a lag of 0 . Catches of the 2 blennies (Blenniid Type 2 and Ophioblennius atlanticus) were poorly correlated with most wind variables (Table 2).

In addition to wind strength and direction, nightly catches of each species were cross-correlated with 4 other environmental variables (tidal range, rainfall, solar radiation and water temperature). These correlations were generally weak or non-significant; however, catches of 7 species during the dry season and 5 species during the wet season were weakly correlated with water temperatures (Table 3).

Nightly catches of Astrapogon puncticulatus were weakly correlated with tidal range and water temperatures over the dry season, at a lag of 2 nights (Table 3 ). Tidal range was also correlated with catches of Eucinostomus melanopterus during the wet season and Stegastes partitus during the dry season at lags of 2 nights and catches of $S$. partitus at a lag of 5 nights during the wet season (Table 3). Similar correlations

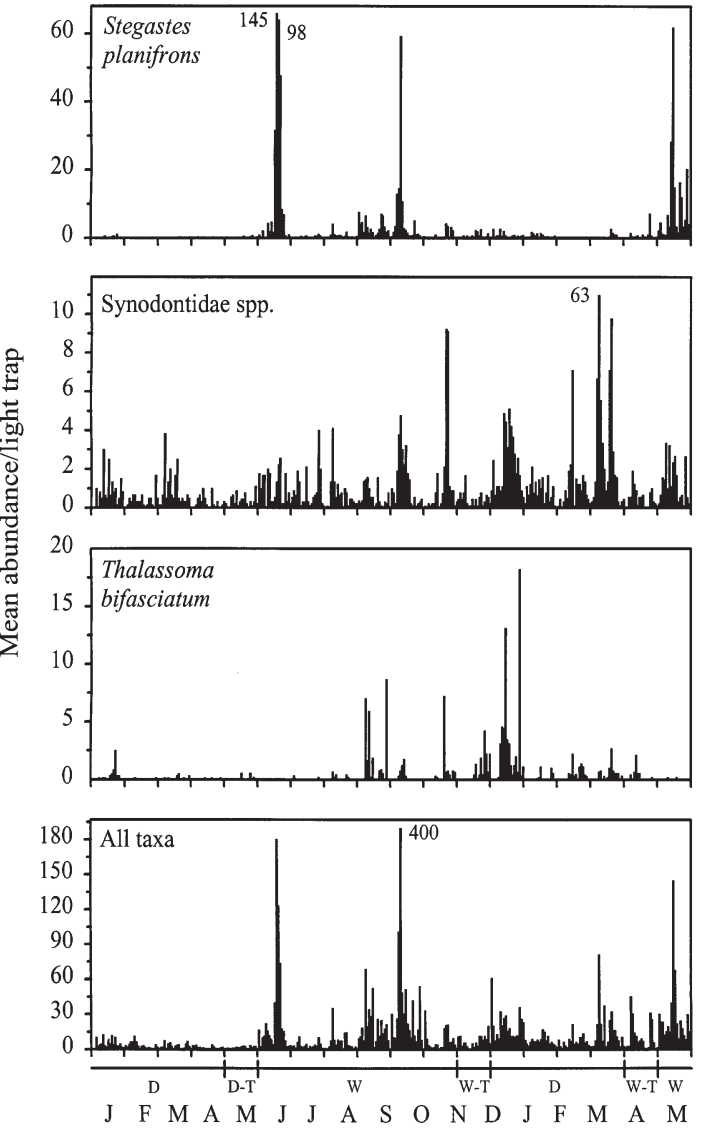

Fig. 5. Nightly catches of pre-settlement Stegastes planifrons, Synodontidae spp., Thalassoma bifasciatum and all taxa combined. Time series and symbols as for Fig. 3

between catches and tidal range were recorded for Lutjanus mahogani and Synodontidae spp. There were weak, negative correlations between solar radiation and catches of 7 species, while rainfall was poorly correlated with catches of only 2 species during both seasons.

During the dry season, catches of all species except Blenniid Type 2, Ophioblennius atlanticus, Synodontidae spp. and Thalassoma bifasciatum, were positively correlated with water temperature at short lags (0 to 2 nights), although some of these relationships were weak (Table 3). The strongest correlations occurred between water temperatures and catches of the 2 lutjanid species and Eucinostomus melanopterus in the dry season (Table 3). Water temperature was also correlated with the combined catches of all taxa in traps at a lag of 5 nights in the wet season and at a lag of 0 nights in the dry season. Water temperatures during the wet season were positively correlated with catches of Stegastes partitus and Synodontidae spp., but were negatively correlated with catches of Lutjanus apodus, L. mahogani and S. dorsopunicans (Table 3). Gener- 
Table 3. Cross-correlation coefficients (r) from comparisons of tidal range, rainfall, solar radiation and water temperature with catches of the 11 most abundant taxa collected by light traps during 19 nights of sampling centred on the new moon in each of 18 consecutive lunar cycles from 31 December 1996 to June 1998. Data sets of catches and environmental variables were concatenated into single time series prior to analyses. ns: not significant at $2 \times$ SE. Lag in nights for correlation shown in parentheses. All: analysis using the entire time series $(\mathrm{n}=342$ nights); Wet: wet season time series comparison $(\mathrm{n}=171$ nights); Dry: dry season time series $(\mathrm{n}=171$ nights $)$

\begin{tabular}{|c|c|c|c|c|c|c|c|c|c|c|c|c|}
\hline \multirow[t]{2}{*}{ Taxa } & \multicolumn{3}{|c|}{ Tidal range -} & \multicolumn{3}{|c|}{$\longrightarrow$ Rainfall $\longrightarrow$} & \multicolumn{3}{|c|}{ - Solar radiation - } & \multicolumn{3}{|c|}{ — Water temperature - } \\
\hline & All & Wet & Dry & All & Wet & Dry & All & Wet & Dry & All & Wet & Dry \\
\hline Astrapogon puncticulatus & ns & ns & $0.19(2)$ & ns & ns & ns & ns & ns & ns & ns & ns & $0.20(2)$ \\
\hline Blenniid Type 2 & ns & ns & ns & ns & ns & ns & ns & ns & ns & ns & ns & ns \\
\hline Eucinostomos melanopterus & $0.13(2)$ & $0.21(2)$ & ns & ns $\quad($ & $0.18(3)$ & ns & ns & ns & $-0.20(3)$ & ns & ns & $0.35(0)$ \\
\hline Lutjanus apodus & $0.12(2)$ & ns & ns & ns & ns & ns & $0.13(4)$ & ns & $-0.22(5)$ & ns & $-0.28(6)$ & $0.44(1)$ \\
\hline Lutjanus mahogani & ns & $-0.20(1)$ & ns & ns & ns & ns & $-0.15(2)$ & $-0.18(2)$ & ns & $-0.18(4)$ & $-0.19(1)$ & $0.39(0)$ \\
\hline Ophioblennius atlanticus & ns & ns & ns & ns & ns & $\mathrm{ns}$ & ns & ns & ns & $0.12(4)$ & ns & ns \\
\hline Stegastes dorsopunicans & $-0.13(0)$ & ns & $0.19(1)$ & $0.14(0)$ & ) ns & $\mathrm{ns}$ & $\mathrm{ns}$ & $0.19(4)$ & $\mathrm{ns}$ & $-0.13(1)$ & $-0.19(1)$ & $0.20(1)$ \\
\hline Stegastes partitus & ns & $0.21(5)$ & $0.22(2)$ & ns & ns & ns & $0.13(4)$ & ns & ns & $0.22(4)$ & $0.28(4)$ & $0.30(2)$ \\
\hline Stegastes planifrons & ns & ns & ns & ns & ns & ns & $-0.13(6)$ & ns & ns & $-0.12(6)$ & ns & $0.23(1)$ \\
\hline Synodontidae spp. & ns & ns & $0.19(3)$ & ns & ns & ns & ns & $-0.20(1)$ & ns & $-0.13(0)$ & $0.24(4)$ & ns \\
\hline Thalassoma bifasciatum & ns & ns & ns & ns & ns & ns & ns & ns & ns & ns & ns & ns \\
\hline All taxa & $-0.15(0)$ & $-0.22(0)$ & ns & ns & ns & $\mathrm{ns}$ & ns & ns & ns & $0.15(5)$ & $0.21(5)$ & $0.27(0)$ \\
\hline
\end{tabular}

ally, catches of Blenniid Type 2, O. atlanticus and T. bifasciatum displayed little correlation with environmental variables.

\section{Correlations between environmental variables averaged over larval durations and light trap catches}

There were few significant correlations between environmental variables (wind component, tidal range, rainfall and solar radiation), averaged over the PLD of the study species, and tight trap catches. However, average daily water temperatures were significantly correlated with catches of 4 species (Lutjanus maho-

Table 4. Correlation coefficients (r) between water temperature and $\log _{10}$ catches of 6 species collected using light traps during 19 nights centred on the new moon in each of 18 consecutive lunar cycles from 31 December 1996 to 3 June 1998. Temperatures were calculated by averaging values during the period of days prior to capture equivalent to mean larval durations of each species. Catches and temperatures were then averaged over 6 night intervals in each lunar month giving $54 x-y$ pairs of data points for analysis (see 'Materials and methods' for details). "Significant at $0.05,{ }^{* *}$ significant at 0.01, using critical values calculated as outlined by Pyper \& Peterman (1998). PLD: planktonic larval duration

\begin{tabular}{|lcccc|}
\hline \multirow{2}{*}{ Species } & \multicolumn{3}{c|}{ PLD } & \\
\cline { 2 - 4 } & Entire & First half & Second half \\
\hline Lutjanus mahogani & $0.47^{* *}$ & $0.44^{*}$ & $0.47^{* *}$ \\
Ophioblennius atlanticus & $\mathrm{ns}$ & $\mathrm{ns}$ & $\mathrm{ns}$ \\
Stegastes dorsopunicans & $0.52^{*}$ & $0.54^{*}$ & $0.48^{*}$ \\
Stegastes partitus & $0.46^{*}$ & $\mathrm{~ns}$ & $0.49^{*}$ \\
Stegastes planifrons & $0.48^{*}$ & $0.44^{*}$ & $0.51^{* *}$ \\
Thalassoma bifasciatum & $\mathrm{ns}$ & $\mathrm{ns}$ & $\mathrm{ns}$ \\
& & & \\
\hline
\end{tabular}

gani, Stegastes dorsopunicans, S. partitus and S. planifrons, Table 4, Figs $7 \& 8$ ). Of these, 3 displayed significant correlations in both halves of the PLD, although there was no clear trend of greater correlation

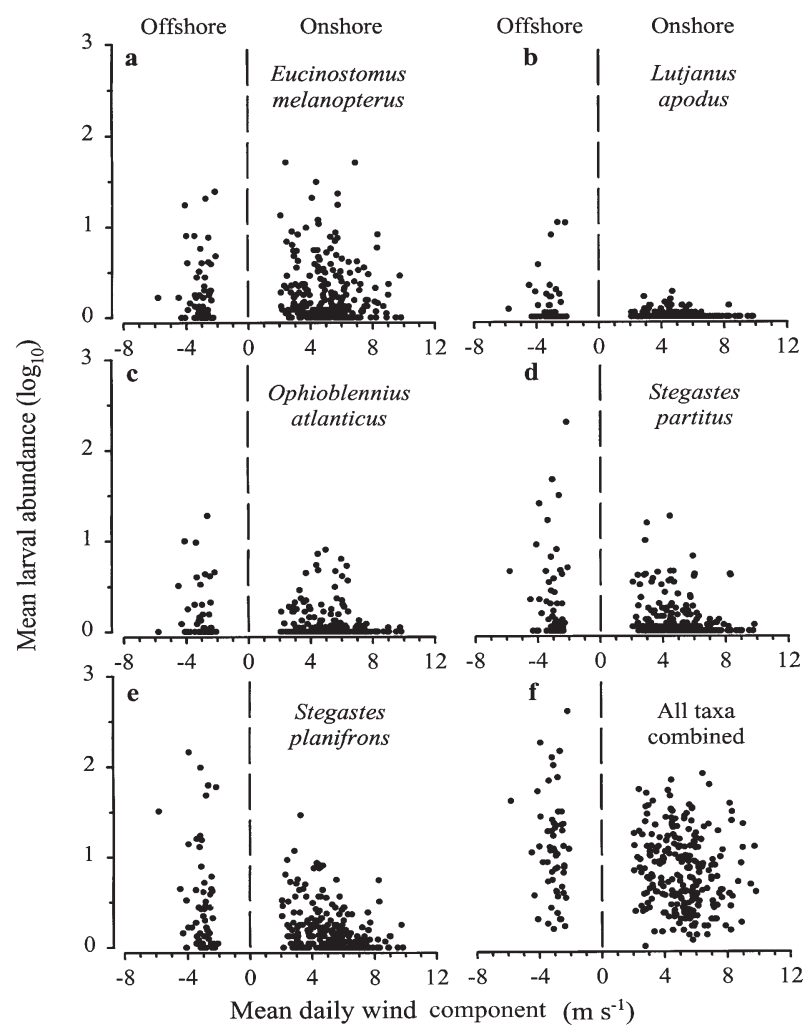

Fig. 6. Mean daily wind component $\left(\mathrm{m} \mathrm{s}^{-1}\right)$ versus nightly light trap catches $\left(\log _{10}\right.$ transformed) of pre-settlement (a) Eucinostomus melanopterus, (b) Lutjanus apodus, (c) Ophioblennius atlanticus, (d) Stegastes partitus, (e) S. planifrons, and (f) all taxa combined 


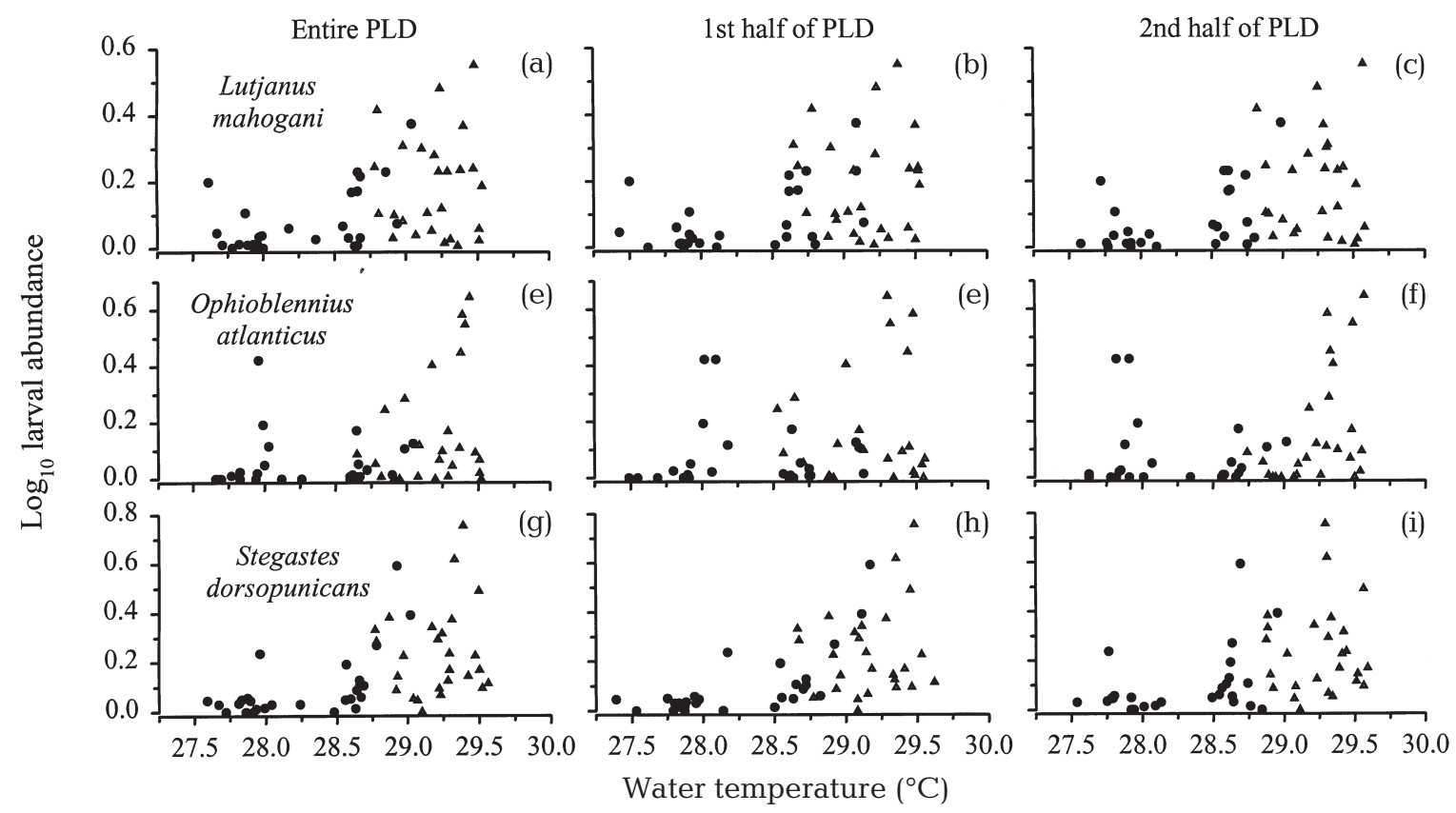

Fig. 7. Water temperature versus $\log _{10}$ abundance of pre-settlement (a-c) Lutjanus mahogani, (d-f) Ophioblennius atlanticus and $(\mathrm{g}-\mathrm{i})$ Stegastes dorsopunicans. Temperatures were calculated by averaging values during the period of days prior to capture equivalent to the mean PLD of each species. Catches and temperatures were then averaged over $6 \mathrm{~d}$ intevals in each lunar month, giving $54 x-y$ pairs of data points. Analyses were repeated using water temperatures from days prior to capture equivalent to only the first or second halves of the PLD of each species (see 'Materials and methods' for details). $\mathbf{A}$ : wet season;

-: dry season

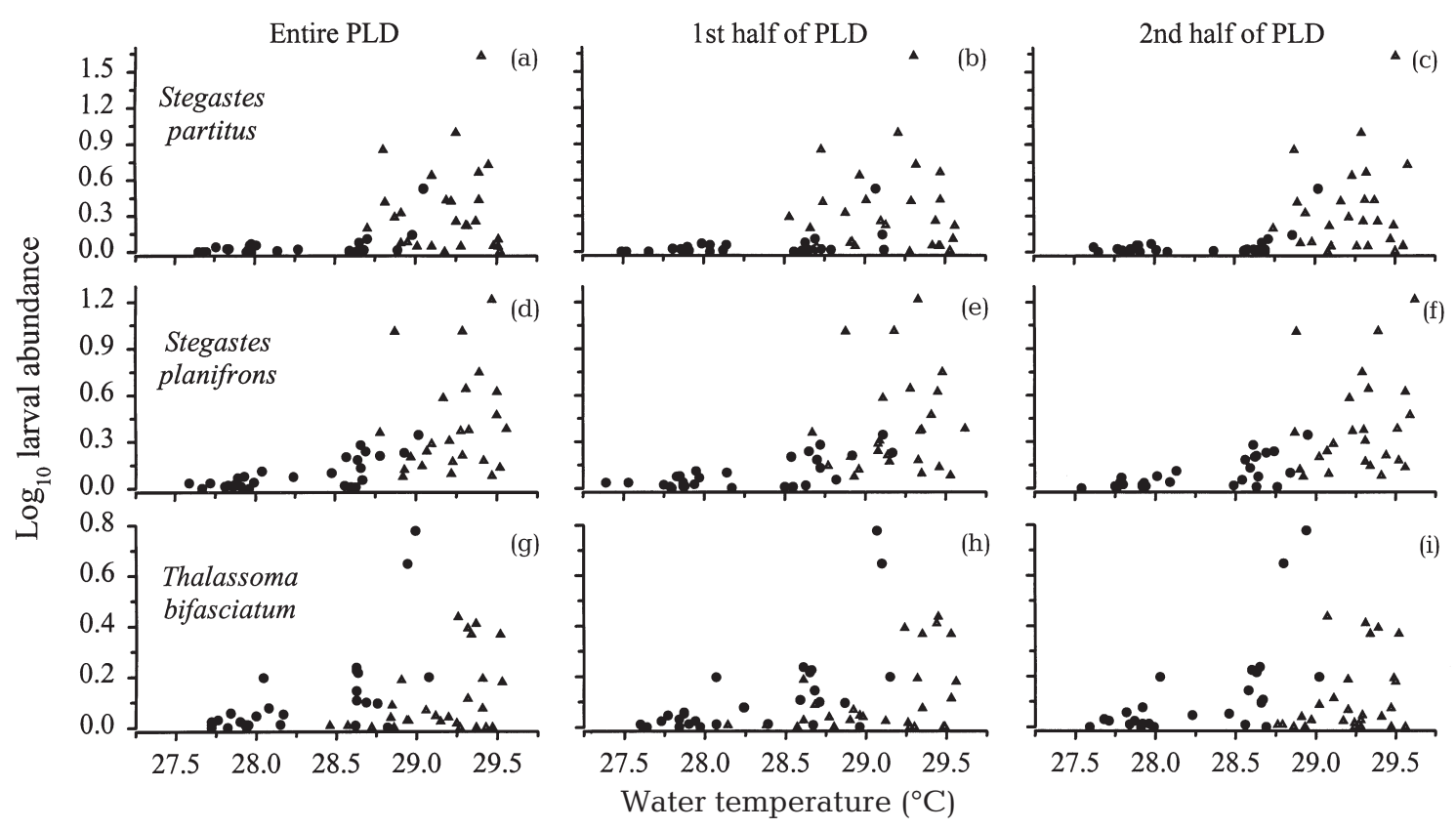

Fig. 8. Water temperature versus $\log _{10}$ abundance of pre-settlement (a-c) Stegastes partitus, (d-f) S. planifrons, and (g-i) Thalassoma bifasciatum. Catches and temperatures were averaged and analysed as for Fig. 7 (see 'Materials and methods' for details). $\mathbf{\Delta}$ : wet season; $\bullet$ : dry season 
Table 5. Results of multiple-regression analyses between water temperature and $\log _{10}$ abundance of pre-settlement reef fishes collected using light traps during 19 nights centred on the new moon in each of 18 consecutive lunar cycles from 31 December 1996 to 3 June 1998. Temperatures were calculated by averaging values during the days immediately prior to date of capture equivalent to the mean planktonic larval durations (PLD) of each species. Catches and temperatures were then averaged over 6 night intervals in each lunar month giving $54 x-y$ pairs of data points for analysis (see 'Materials and methods' for details). Analyses were repeated using water temperatures from days prior to capture equivalent to only the first or second halves of the PLD. ns: no significant model identified

\begin{tabular}{|llcc|}
\hline Dependent variable & Larval stage & $\mathrm{R}^{2}$ & $\mathrm{p}$ \\
\hline Lutjanus mahogani & Mean PLD & 0.22 & 0.0003 \\
& First half & 0.20 & 0.0008 \\
& Second half & 0.22 & 0.0004 \\
Ophioblennius atlanticus & Mean PLD & 0.09 & 0.0300 \\
& First half & $\mathrm{ns}$ & $\mathrm{ns}$ \\
& Second half & 0.09 & 0.0230 \\
Stegastes dorsopunicans & Mean PLD & 0.27 & $<0.0001$ \\
& First half & 0.29 & $<0.0001$ \\
& Second half & 0.23 & 0.0003 \\
Stegastes partitus & Mean PLD & 0.21 & 0.0005 \\
& First half & 0.17 & 0.0019 \\
& Second half & 0.23 & 0.0003 \\
Stegastes planifrons & Mean PLD & 0.23 & 0.0002 \\
& First half & 0.20 & 0.0008 \\
Thalassoma bifasciatum & Second half & 0.26 & $<0.0001$ \\
& Mean PLD & 0.10 & 0.0106 \\
& First half & 0.16 & 0.0031 \\
& Second half & 0.08 & 0.0428 \\
\hline
\end{tabular}

in either the first or second half of the larval period. Catches of Ophioblennius atlanticus and Thalassoma bifasciatum were not correlated with environmental variables (Table 4).

Multiple-regression analysis detected no combined effects of the environmental variables on catches of any of the 6 species. Water temperatures were again identified as the only variable correlated with catches, although this accounted for only a small amount of the variance in the data $\left(\mathrm{R}^{2}=0.08\right.$ to 0.29 ; Table 5$)$.

\section{DISCUSSION}

This study compared both wind speed and direction with nightly patterns of replenishment of 11 species of reef fishes in the San Blas Archipelago, using time series analyses. Of these species, 8 displayed significant correlations between catches in light traps and wind speeds at short lags. However, catches and wind variables were weakly correlated and the signs of correlations were sometimes inconsistent. For example, catches of Stegastes dorsopunicans were positively correlated with wind speeds during the wet season, but negatively correlated during the dry season.

Weak correlations between winds and the replenishment of Thalassoma bifasciatum were consistent with the results of previous studies. Robertson et al. (1999) found little correlation between wind patterns and daily and monthly recruitment (estimated by collections from small patch reefs) of this species at San Blas during 11 yr. These workers concluded that either the currents that deliver settlers to reefs were not influenced by short-term fluctuations in wind, or that the settlement of $T$. bifasciatum may be driven by environmental and biological processes other than transport mechanisms.

During the wet season, when the majority of presettlement fishes were collected by traps, winds were usually weak ( 2 to $4 \mathrm{~m} \mathrm{~s}^{-1}$ ) and offshore. Offshore wind strengths of this magnitude might produce currents that are insufficient to prevent active onshore migration of larvae at most times and may contain stimuli for settlement, enabling larvae to detect reefs and respond by actively migrating to suitable habitats. Such behaviour is thought to determine settlement patterns of reef fishes on the GBR (Doherty et al. 1996, Kingsford 1997).

This idea assumes that larvae are capable of swimming against surface currents created by offshore winds, which seems likely since many are strong swimmers that are able to travel great distances in relatively short periods of time (Leis \& Carson-Ewart 1997, Stobutzki \& Bellwood 1997). Interestingly, the species whose catches were most strongly correlated with offshore winds was the lutjanid, Lutjanus apodus. Leis \& Carson-Ewart (1997) examined swimming ability in a range of reef fish larvae and found members of this family were among the most proficient and were able to swim against strong currents $\left(20\right.$ to $40 \mathrm{~cm} \mathrm{~s}^{-1}$ ).

Alternatively offshore winds may drive oceanographic processes such as Ekman transport and upwelling that might result in the delivery of larvae to reefs. For example, Pitts (1999) found that upwelling along the central Atlantic Coast of Florida transported fish and crustacean larvae across the shelf and towards the shore. Similar results were recorded by Hamann et al. (1981) in a study of the Mauritanian upwelling area and by Brubaker et al. (2000) along the coast of North Carolina. It is difficult to determine if such physical processes also operate in San Blas, as the influence of wind speed and direction on surface currents and the oceanography of the local region is largely unknown.

Weak or non-significant correlations between the intensity of nightly replenishment and potential transport mechanisms such as current flow or wind speed and direction suggest that variation in catches of the 
study species might be driven by processes influencing survivorship throughout the larval phase. However, few correlations were found between environmental variables and light trap catches when these variables were averaged over the larval durations of the study species. Only water temperature was consistently correlated with catches of 4 of the 6 species included in analyses. Water temperatures during both the first and second halves of the PLD were moderately correlated with catches of Lutjanus mahogani, Stegastes dorsopunicans and S. planifrons. Catches of S. partitus were correlated with water temperature during the second but not the first half of the PLD.

In temperate environments, correlations between water temperatures and year-class success of marine fishes are well-documented (Cushing 1982, Koslow 1984, Sharp 1991) and may result from both direct and indirect influences on the survivorship of larvae in the plankton. Theoretical studies suggest that warm temperatures raise metabolic and growth rates of larvae, reducing the amount of time they remain in the vulnerable planktonic stage and thus lowering mortality rates, but also making larvae more susceptible to starvation (Houde 1989). Higher water temperatures may also increase primary and secondary production in planktonic food chains, ensuring better feeding conditions for larvae (Heath 1992). Such processes may account for the positive correlations between water temperature and light trap catches in San Blas; however, they are unlikely to be the sole factor governing replenishment, since such correlations accounted for only moderate amounts of the variance in the data sets.

The lack of correlations between catches and environmental variables (averaged over larval durations) other than water temperature in San Blas may be due to a number of factors. Only a restricted subset of environmental variables were examined and it is possible that other, unmeasured variables (e.g. salinity, primary productivity), may contribute significantly to variability in replenishment patterns. Additionally the environmental variables measured at San Blas Point might differ from those actually experienced by larvae during the initial stages of development and dispersal in the plankton.

A lack of correlations between environmental variables and replenishment would also be expected if patterns were largely driven by the spawning output of the study species. However, earlier studies show this not to be the case. Robertson et al. $(1988,1993)$ demonstrated that changes in the magnitude of monthly spawning of 4 of the 6 study species were not correlated to subsequent recruitment patterns in the Archipelago. These workers also found that variation in monthly recruitment strength of Stegastes partitus exceeded that of spawning output by as much as 4 - to
20 -fold, and concluded that the magnitude of recruitment of this species was primarily controlled by processes operating within the plankton (Robertson et al. 1988).

The failure to detect consistent correlations between replenishment and environmental variables using daily and pooled time series may also be due to the pooling of larvae of different ages at capture in analyses. The extent to which larval durations of reef fishes may differ both among individuals and with time is largely unknown, although some studies suggest that such variation can be considerable. For example, McCormick (1994) found that the PLD of newly settled individuals of the goatfish Upeneus tragula collected at a single locality on the GBR at different times ranged in duration by up to $40 \%$ of mean values. If the larval durations of the species used in the correlation analyses were highly variable, this would reduce the power of statistical tests to detect significant correlations between environmental variables and replenishment patterns. This problem was compounded by night-tonight variations in light trap catches, which largely reflects small-scale patchiness in spatial distribution of larvae within the plankton (Milicich \& Doherty 1994, Wilson 2001). We attempted to reduce these sources of variation by pooling time series of environmental variables and light trap samples into intervals of 6 nights in each month of sampling and transforming catches to $\log _{10}$ values in order to reduce the influence of strong peaks of abundance in the analysis.

An alternative approach would have been to use otolith analysis to estimate the larval durations of individuals in the comparisons. This information could then have been used to convert light trap catches into records of hatch dates that could be compared with environmental variables on a day to day basis (see Wilson \& Meekan in press). However, otolith analysis is an extremely time-consuming process, and was not logistically feasible since we wished to examine numerous species over the broad time period of the study.

In summary, few strong correlations were found between environmental variables and patterns of replenishment either at the time of settlement or when averaged over larval durations. The lack of correlations between environmental time series and day to day patterns in light trap catches might be due to the behavioural abilities of young fish, which may override physical forcing such that only extreme events (e.g. storms; Shenker et al. 1993) have a marked influence on replenishment patterns. There were positive correlations between light trap catches and water temperatures averaged over the larval phase of some species that may have resulted from the effects of temperature on growth rates and/or feeding conditions of larvae. Although significant, these correlations accounted for 
only a small amount of the variance in light trap catches. Other, unmeasured variables, including those of non-local origin, may exert a stronger influence on light trap catches and future studies should aim to include a greater range of environmental variables, both at the site of replenishment and along possible dispersal paths of larvae.

Acknowledgements. We thank M. McCormick and the anonymous reviewers for comments on drafts of the manuscript. Thanks also to L. Vigliola and J. McIlwain for assistance with statistical analysis and to D. R. Robertson for logistical support. M. Wilson, I. Hendriks, E. Vytopil, E. Pena, M. Griffin, U. Anlauf and M. MacKenzie provided field assistance. Funds from the following institutions facilitated this research: James Cook University (DW: APRA, DMRS, MRG), Australian Institute of Marine Science, Smithsonian Tropical Research Institute (DW: ROF) and the National Geographic Society of America (NGS\#5395-94). We acknowledge the Kuna General Congress and the government of the Republic of Panamà for permitting fieldwork in the San Blas region.

\section{LITERATURE CITED}

Brubaker J, Hoof R, Shanks AL, Largier J, Brink L (2000) Demonstration of the onshore transport of larval invertebrates by the shoreward movement of an upwelling front. Limnol Oceanogr 45:230-236

Chatfield C (1997) The analysis of time series: an introduction. Chapman \& Hall, New York

Cowen RK, Sponaugle S (1997) Relationships between early life history traits and recruitment among coral reef fishes. In: Chambers RC, Trippel EA (eds) Early life history and recruitment in fish populations. Chapman \& Hall London, p 423-449

Cushing DH (1982) Climate and fisheries. Academic Press, London

Cushing DH (1995) The long-term relationship between zooplankton and fish. ICES J Mar Sci 52:611-626

Doherty PJ, Kingsford M, Booth DJ (1996) Habitat selection before settlement by Pomacentrus coelestis. Mar Freshw Res 47:391-399

Gallego A, Heath MR, McKenzie E, Cargill LH (1996) Environmentally induced short-term variability in the growth rates of larval herring. Mar Ecol Prog Ser 137:11-23

Hamann I, John HCh, Mittelstaed E (1981) Hydrography and its effect on fish larvae in the Mauritanian upwelling area. Deep-Sea Res 28:561-575

Heath MR (1992) Field investigations of the early life stages of marine fish. Adv Mar Biol 28:1-174

Houde ED (1989) Comparative growth, mortality, and energetics of marine fish larvae: temperature and implied latitudinal effects. Fish Bull 87:471-495

Kingsford MJ, Finn M (1997) The influence of phase of the moon and physical processes on the input of presettlement fishes to coral reefs. J Fish Biol 51(Suppl A):176-205

Koslow JA (1984) Recruitment patterns in northwest Atlantic fish stocks. Can J Fish Aquat Sci 41:1722-1729

Leis JM, Carson-Ewart BM (1997) In situ swimming speeds of the late pelagic larvae of some Indo-Pacific coral-reef fishes. Mar Ecol Prog Ser 159:165-174

Leis JM, Carson-Ewart BM (1999) In situ swimming and settlement behaviour of larvae of an Indo-Pacific coral- reef fish, the coral trout Plectropomus leopardus (Pisces: Serranidae). Mar Biol 134:51-64

Leis JM, Sweatman HPA, Reader SE (1996) What the pelagic stages of coral reef fishes are doing out in blue water: daytime field observations of larval behavioural capabilities. Mar Freshw Res 47:401-411

McCormick MI (1994) Variability in age and size at settlement of the tropical goatfish Upeneus tragula (Mullidae) in the northern Great Barrier Reef lagoon. Mar Ecol Prog Ser 103:1-15

Milicich MJ (1994) Dynamic coupling of reef fish replenishment and oceanographic processes. Mar Ecol Prog Ser 110:135-144

Milicich MJ, Doherty PJ (1994) Larval supply of coral reef fish populations: magnitude and synchrony of replenishment to Lizard Island, Great Barrier Reef. Mar Ecol Prog Ser 110:121-134

Pitts PA (1999) Effects of summer upwelling on the abundance and vertical distribution of fish and crustacean larvae off Florida's Atlantic coast. J Exp Mar Biol Ecol 235:135-146

Pyper B, Peterman R (1998) Comparisons of methods to account for autocorrelation in correlation analyses of fish data. Can J Fish Aquat Sci 55:2127-2140

Robertson DR (1990) Differences in the seasonalities of spawning and recruitment of some small neotropical reef fishes. J Exp Mar Biol Ecol 144:49-62

Robertson DR (1992) Patterns of lunar settlement and early recruitment in Caribbean reef fishes at Panamà. Mar Biol 114:527-537

Robertson DR, Green DG, Victor BC (1988) Temporal coupling of production and recruitment of larvae of a Caribbean reef fish. Ecology 69:370-381

Robertson DR, Schober UM, Brawn JD (1993) Comparative variation in spawning output and juvenile recruitment of some Caribbean reef fishes. Mar Ecol Prog Ser 94: $105-113$

Robertson DR, Swearer SE, Kaufmann K, Brothers EB (1999) Settlement vs environmental dynamics in a pelagicspawning reef fish at Caribbean Panama. Ecol Monogr 69(2):195-218

Sharp GD (1991) Climate and fisheries: cause and effect-a system review. In: Kawasaki $\mathrm{T}$, Tanaka $\mathrm{S}$, Toba $\mathrm{Y}$, Taniguchi A (eds) Long-term variability of pelagic fish populations and their environment. Pergamon Press Tokyo, p 239-258

Shenker JM, Maddox ED, Wishinski E, Pearl A, Thorrold SR Smith N (1993) Onshore transport of settlement-stage Nassau grouper Epinephelus striatus and other fishes in Exhuma Sound, Bahamas. Mar Ecol Prog Ser 98:31-43

Sponaugle S, Cowen RK (1997) Early life history traits and recruitment patterns of Caribbean wrasses (Labridae). Ecol Monogr 67:177-202

Stobutzki IC, Bellwood DR (1997) Sustained swimming abilities of the late pelagic stages of coral reef fishes. Mar Ecol Prog Ser 149:35-41

Stobutzki IC, Bellwood DR (1998) Nocturnal orientation to reefs by late pelagic stage coral reef fishes. Coral Reefs $17: 103-110$

Theilacker GH, Bailey KM, Canino MF, Porter SM (1996) Variations in larval walleye pollock feeding and condition-a synthesis. Fish Oceanogr 5:112-123

Thorrold SR, Shenker JM, Wishinski E, Mojica R, Maddox ED (1994a) Larval supply of shorefishes to nursery habitats around Lee Stocking Island, Bahamas. I. Small-scale distribution patterns. Mar Biol 118:555-566

Thorrold SR, Shenker JM, Maddox ED, Mojica R, Wishinski E 
(1994b) Larval supply of shorefishes to nursery habitats around Lee Stocking Island, Bahamas. II. Lunar and oceanographic influences. Mar Biol 118:567-578

Thorrold SR, Shenker JM, Mojica R, Maddox ED, Wishinski E (1994c) Temporal patterns in the larval supply of summerrecruiting reef fishes to Lee Stocking Island, Bahamas. Mar Ecol Prog Ser 112:75-86

Victor BC (1986a) Delayed metamorphosis with reduced larval growth in a coral reef fish (Thalassoma bifasciatum). Can J Fish Aquat Sci 43:1208-1213

Victor BC (1986b) Duration of the planktonic larval stage of

Editorial responsibility: Otto Kinne (Editor),

Oldendorf/Luhe, Germany one hundred species of Pacific and Atlantic wrasses (family Labridae). Mar Biol 90:317-326

Wellington GM, Victor BC (1989) Planktonic larval duration of one hundred species of Pacific and Atlantic damselfishes (Pomacentridae). Mar Biol 101:557-567

Wilson DT (2001) Patterns of replenishment of coral-reef fish in the nearshore waters of the San Blas Archipelago, Caribbean Panamà. Mar Biol 139:735-753

Wilson DT, Meekan MG (in press) Growth related advantages for survival to the point of replenishment in a coral-reef fish, Stegastes partitus (Pomacentridae). Mar Ecol Prog Ser

Submitted: September 8, 2000; Accepted: February 20, 2001 Proofs received from author(s): October 24, 2001 